\title{
Explaining Japan's Saving Rate
}

\section{by}

David W. Campbel1*

Working Paper No. 135

January 1995

*Contemporary Japan Center, Essex University, Wivenhoe Park, Colchester, C04 35Q, UK 


\section{Introduction}

This paper examines what I believe to be the significant developments in research over the past ten years on Japan's saving. It is a world that has been turned upside down during this period. I hope this paper helps clarify the extraordinary changes that have taken place.

The paper is organized as follows. The next section motivates why Japan's saving is important. It is followed by a section which reviews the literature on the standardization of US-Japanese saving rates. Next comes my analysis of the Japan is special argument as applied to saving. After that I look at heterogeneity in saving, an idea which I suspect will dominate the research on Japan's

* I am grateful to Charles Horioka for his comments and advice on this paper. Comments from John Laitner were also most useful. Fumio Hayashi kindly supplied me with the data used to draw Figures 1 and 2. Part of this paper was written while I was a visiting Scholar at the Institute of Social Science of the University of Tokyo. I would like to thank Masahiro Kawai and the Institute for hosting me. Grants from the British Academy and the Social science Research Council are gratefully acknowledged. 
saving for the next several years. Finally I end with a brief summary

\section{The Importance of Japanese Saving}

Saving in Japan has been the focus of a great deal of interest for three reasons. First, saving has provided the funds for investment that have fueled the extraordinary growth of the Japanese economy over the postwar period. Second, with the reduction in net business borrowing in Japan after the mid-1970's and with the increase in net government saving after 1978, the continued relatively high level of household saving has since 1983 been translated into a string of large current account surpluses. Third, the Japanese example has been an object lesson for US policy makers, many of whom now feel that greater fiscal discipline and increased private saving in the US would lead to an improvement in the US's current account, greater growth and increased US international competitiveness.

These points will become evident from an examination of Tables 1 to 5.1 Table 1 presents a breakdown of saving, investment, and saving minus investment (this last item represents the amount of funds available for investment in other sectors or overseas) for the three sectors in Japan over the postwar era. Through 1974 the

1. Tables $1,3,4$, and 5 of this paper are updated and slightly modified versions of respectively Tables $1,2,3$, and 4 of Horioka (1989). Further much of this section of my paper follows Horioka (1989) quite closely. 
story is a simple one. A high sustained level of household saving and a modest amount of household investment leads to a household S-I balance of about 9 to 10 percent of net national product (NNP). The business sector during these years is a mirror image of the household sector: modest saving and high levels of investment, which result in net borrowing needs of about 9 to 10 percent of NNP. In addition the government sector typically runs a small surplus. In brief the business sector borrowed massive amounts of money from the household sector to finance its hugh investment requirements; the government balanced its budget, and there were no current account imbalances to speak of.

After 1974 the net borrowing needs (S-I) of the business sector declined several percentage points. This presumably was the result of a reassessment by business of future growth prospects of the economy. In any case over time this became in my view a selffulfilling prophecy. The government in the wake of the first oil shock began running huge deficits. There are two standard explanations of this. First, the government was hoping to return the economy to its previous growth path by the stimulus of expansionary fiscal policy. Second, with the dramatic slowdown of the economy tax receipts dropped sharply. By 1979 government fiscal policy had turned around, and in fact the government ran substantial budget surpluses from 1988 to 1992. Decreased net borrowing by the corporate sector and increasing net saving by the government in the light of continued robust household saving led to the post-1982 series of current account surpluses detailed in 
Table 2 .

Table 3 is an abridged version of Table 1 but for the US. The figures in both tables are those from the official national accounts of the two countries, and no adjustments of any kind have been made to them. Saving and investment patterns are much more straightforward in the US than Japan. The private saving rate during the 50's, 60's, and 70's was very steady, averaging around 9 percent, and much less than the Japanese private saving rate. In the 80's the US private saving rate decreased somewhat. Why this occurred is unknown, but this recent decrease has become something of a red flag for US policy makers. Net private domestic investment has with some exceptions matched private saving dollar for dollar. Hence the current account for the most part has been driven by the government budget deficit or surplus. It is only since 1983 that current account imbalances have been a persistent political problem.

Finally in support of the third point of the first paragraph of this section, I would like to suggest that there is a connection between saving, investment, and growth. Actually while it may come as something of a surprise to non-economists, there is no consensus among economists on how to model aggregate saving or growth for either Japan or the US. I will return to this issue later in this paper. Given this lack of generally accepted models, rather than formally linking saving, investment, and growth, I would prefer to appeal to the well known empirical regularity discovered by Feldstein and Horioka (1980) that for OECD countries in the 1960's 
and 70's a sustained one percent increase in the saving rate of a country induced nearly a one percent increase in the country's investment rate. ${ }^{2}$ A follow-up study, Feldstein and Bacchetta (1991), indicates that for 1980-86 the above elasticity while still substantial is smaller than 1. It makes sense then to believe that extra saving will largely be domestically invested leading to a larger capital stock and consequently greater growth.

Substantial evidence for this is presented in Tables 4 and 5 . In Table 4 we see that Japan's private saving rate has greatly outstripped that of the Us for every five-year period since 1955. Indeed comparing the 38-year overall averages Japan's rate has been 2.1 times larger than the US's ( 17.1 percent versus 8.1 percent). When private saving is broken down into household and business saving the corresponding ratios are 2.4 and $1.6 .^{3}$ Turning to Table 5 we see that real gross domestic product has increased much faster in Japan than the US, and again it is true for every five-year period since 1955. Comparing these overall averages we see that Japan's growth rate has been 2.2 times higher than the US's (6.5 percent versus 2.9 percent). Indeed the story is even more dismal if we look at per capita growth rates.

2. This is an indirect quotation of a statement on page 201 of Feldstein and Bacchetta (1991).

3. To be more precise these figures are for the 1955-87 period and are for saving rates expressed in terms of gross national product. See Horioka (1989), Table 3. 
Standardizing Definitions: A Comparison of US-Japan Saving Rates

The work in this area has had a profound impact on our understanding of Japan's saving. The pioneering article was Hayashi (1986), and he deserves a great deal of credit for, one, realizing that there are significant differences in the way American and Japanese saving rates are calculated and for, two, devising a method to make the saving rates of the two countries directly comparable. Hayashi's analysis has I think largely carried the day among specialists. However one should note that Dekle and summers (1991) sharply take issue with Hayashi's methodology. Perhaps it is not too unfair to quote Hayashi on Dekle and Summers (1991): "Of all the points raised in DS, the only one which I think has any merit is the treatment of okinawa's capital stock....As much as I appreciate the effort and interest paid by DS, I view their work as wholly misguided." 4 For the latest developments on this topic see Horioka (May 1994), Hayashi (1994), and Iwamoto (1994).

To see what this work has bought I would like to turn to Figures 1 and $2 .^{5}$ Figure 1 compares the US and Japanese national saving rates from 1955 to 1990 . The gap between the unadjusted

4. Hayashi (1991), pp. 86-7. The emphasis is in the original.

5. Hayashi 's most recently calculated saving rates, which appear in Hayashi (1994), do not differ significantly from those shown in Figures 1 and 2 of this paper with two exceptions. The first (second) is that the rather erratic pattern of the fully adjusted Japanese national (private) saving rate in Figure 1 (2) for the period 1956 to 1963 has been dramatically smoothed out. The new rates were not reproduced here since complete data was not presented in all cases in Hayashi (1994). 
Japanese rate and the US rate has been huge over this period; this comes as no surprise given our results in the previous section.

The two rates can be made comparable by adjusting the Japanese rate for government investment and historical cost (book value) depreciation. In the US government saving is defined to be the government budget surplus (government investment is treated as if it were zero). In Japan government investment is explicitly recognized; hence it must be subtracted off to make the definitions agree. The second line from the top in Figure 1 makes this adjustment. It turns out to make a big difference since Japanese government investment has been in the 5 to 6 percent range of NNP in the postwar period.

The next line down from the top makes the adjustment for historical cost depreciation. ${ }^{6}$ In the US depreciation is replacement cost depreciation. An example will clarify how these concepts differ. If the roof on your house needs to be replaced, historical cost depreciation is equal to the original cost of the roof; replacement cost depreciation is equal to the cost of the new roof. Saving is net of depreciation; hence in an inflationary environment historical cost depreciation overstates saving. Making this adjustment reduces the US-Japan saving gap by several percentage points after 1973 .

Comparing the two lower lines of the graph, it is clear that

6. It also adjusts for capital transfers, which are excluded from saving in Japan and included in the US. This adjustment is insignificant for the national saving rate but does affect the sectoral allotment of national saving (see Hayashi (1994)). 
Japanese national saving was much higher than US saving in the 1965 to 1975 period and that the saving rates converged in the late $70^{\prime} \mathrm{s}$ before diverging dramatically after 1983. Since differing fiscal policies may have affected the saving gap particularly post-1983, Figure 2 presents the US private saving rate and the fully comparable Japanese private saving rate (these are just the two lower lines of Figure 1 with the government budget surpluses/deficits removed).

our suspicions that the divergence in national saving rates in recent years has been due to differing fiscal policies is apparently confirmed. Also it is easy to observe that the private saving rate in Japan during the $1965-75$ period was much higher than the US's. Further the private saving rate gap has narrowed very considerably from its peak around 1970 and has remained approximately constant since 1980 at about 5 to 6 percentage points. In addition if one adjusts the private saving rates for consumer durables the gap is reduced by 2 to 3 percentage points (Hayashi (1986), Horioka (May 1994)), and the US private saving rate comes within striking distance of the Japanese rate. The idea that the Japanese private saving rate is high is fifteen years out of date.

The Japan is Different Hypothesis

The second area of research which during the past ten years has transformed our understanding of Japan's saving is the testing 
of this hypothesis. In brief there has been a school of thought that institutional and other factors peculiar to Japan have contributed importantly to the seemingly high level of the aggregate saving rate. Some of the factors that were identified are: the bonus system, tax breaks for saving, the low level of Social security benefits, high housing prices, the high costs of education, the high costs of marriage, and bequests and other transfers. The best surveys of this material are Horioka (1990) and Horioka (1993).

Although extensive research has been carried out little evidence has been presented that any of these factors have contributed to a high aggregate saving rate, and in fact many of these factors have been shown to be insignificant via-a-vis aggregate saving. In short the Japan is different hypothesis is in critical danger of being declared dead. I look briefly at the three sexiest factors, bonuses, high housing prices, and transfers, below.

The definitive article on the bonus system is Ishikawa and Ueda (1984). I say definitive because no well received study on bonuses and saving has been written since their article appeared. Their main conclusion is that at most the bonus system accounted for 15 percent of the personal saving rate (i.e., at most 1 yen out of every 6.67 yen of saving was due to bonuses) over the years 1958 to 1978. This conclusion was based on the testing of three different kinds of data: cross section, survey, and macro data. My own opinion is that their macro analysis suffered from an ad hoc 
specification that can not be taken seriously, that their survey data results are implausible, and that their cross section data results are weak econometrically. If my view is correct one might ask why this issue has not been seriously reexamined. I think the answer to this is that Ishikawa and Ueda's conclusion--that bonuses at best have played a minor role in aggregate saving--fits neatly with the preconceived notions about bonuses that most economists in Japan hold.

As with the bonus system the number of interesting articles written recently about the impact of high housing prices on aggregate saving has been small. The closest empirical study by far is Horioka (1991).7 with a few assumptions he is able to show that the aggregate amount of housing-related saving of the household sector as a whole (net housing-related saving) equals the sum of saving for the downpayment and saving in the form of housing loan repayments (this sum is gross housing-related saving) minus depreciation.

My Figure 3 is taken directly from Figure 3 of Horioka (1991). This figure shows housing-related saving as a percent of household saving. Looking at net housing-related saving we see that except for post-1982 it has been an insignificant share of aggregate saving. Indeed during 1965-75 when the national and private saving rates were very high housing-related saving represented on average -.9 percent of household saving. Consequently during 1976-82 this ratio became .5 percent. The very sharp increase after 1982, a

7. Horioka (1988) is a preliminary version of this. 
period when the private saving rate was relatively low, is fascinating however.

I would like to turn now to transfers; these are bequests and other gifts. With the publication of Kotlikoff and Summers (1981) the question of how important transfers are in the wealth accumulation process has received a great deal of attention. In the case of Japan interest in this was particularly spurred on by the claim in Hayashi (1986) that "bequests are probably the most important factor" in explaining Japan's high household saving rate. ${ }^{8}$

I summarize selectively the available evidence in Table 6 . I should say something about the three studies listed. The target of all the studies was worker households. This means that roughly 40 percent of households--the unemployed, the retired, the selfemployed--were ignored. The methodology in all three cases was the same, the cumulation of life cycle saving technique. The source materials also in all three were consumer surveys with the Family Income and Expenditure Survey in its various versions playing the largest role. Campbell (1992) and Dekle (1989) used standard definitions of transfers; Hayashi (1986) did not.

Reviewing the results, Dekle (1989) found that the share of transfer wealth in total household wealth for the four cohorts he followed ranged from 3 to 27 percent. Campbell (1992) estimated that for worker households as a whole the ratio was between 0 and 29 percent. Hayashi (1986) did not estimate this ratio, but rather

8. Hayashi (1986), p. 167. 
an annual flow of transfers. His flow of transfers was meant to encompass the entire household sector (he extrapolated his results from worker households). He assessed the size of his flow of transfers in the following way, "Compared with the 1974 year-end aggregate private wealth of 598 trillion, it looks small."9 In summary these three studies in fact agree that transfers have not been very significant in the wealth accumulation process.

\section{Heterogeneity in Saving}

The last major advance in research vis-a-vis Japan's aggregate saving has been the highlighting of the importance of heterogeneity in saving behavior in the US. The abandonment of the stochastic life cycle model (Hall (1978)) by the mid-1980's in the Us and the more recent decisive rejection (Altonji, Hayashi, and Kotlikoff (1992)) of the intergenerational altruism model in the US has spelled the end of the simple idea that one paradigm of saving was adequate to describe aggregate saving in the United states.

Table 7 demonstrates the shocking degree to which the wealth distribution of US saving is skewed and provides powerful evidence that models of US aggregate saving ought to explicitly recognize

9. The quotation is from Hayashi (1986), p. 190. While it is possible to convert a flow of transfers into a stock of transfer wealth if one makes steady state assumptions this involves the estimation of a number of parameters, so I did not attempt to do it here. Horioka (1993) in his Table 7.7 makes a very rough calculation that this flow is equivalent to a share of transfer wealth of 9.6 percent. For a good discussion of these blow-up formulas see Modigliani (1988). 
diversity of saving behavior. ${ }^{10,11}$ According to the table the wealthiest ten percent of Americans in 1986 accounted for 98.4 percent of real saving between 1983 and 1986 and in 1986 held a full 62 percent of the household sectors's assets. Even more strikingly the wealthiest one-half percent of Americans accounted for 41.6 percent of real saving over the period and held an extraordinary 24.4 percent of the household sector's assets. Contrasted to this the poorest ten percent of Americans were responsible for -3.3 percent of real saving and owned only .3 percent of the assets of the household sector. Indeed the poorest 70 percent of Americans as a group actually dissaved $(-20.4$ percent of real saving) and only held 16.8 percent of the household sector's assets. ${ }^{12}$ It seems then that savers can be divided into at least three groups: a substantial number who are liquidity constrained, a relative handful who accumulate vast sums and who may play the leading role in aggregate saving, and of course a large number who fall between these two extremes.

With the rejection of the old models new models have begun to be proposed. Two strands of thought can now be discerned I think. First there are models that incorporate in one model elements of the older competing theories. Perhaps the best example is Laitner

10. Real saving in Table 7 is equal to the real change in wealth over the three-year period. Hence real capital gains are included in real saving; these may well have biased the distribution.

11. Table 7 does not address the important issue of mobility within the wealth distribution. For this see Avery and Kennickell (1991).

12. This is not to say of course that these 70 percent of Americans all dissaved. Many saved, but their saving was less than the amount of dissaving done by others in this group. 
(1992), which sets up an overlapping generations (life cycle) framework with altruism and liquidity constraints. The second strand are models (or proposed models) that break cleanly with the past. For instance the view of Carroll and Summers (1991) is that savers in the US are either buffer stock savers (the vast majority) or the very wealthy (a small number), with the latter group being relatively more important in wealth accumulation. Interestingly they do not posit any kind of model for the very wealthy. However their buffer stock savers follow Deaton $(1990,1992)$ and are identified as the typical consumer, who saves to build up a buffer stock "to smooth consumption over short horizons and to prepare for temporary sharp declines in income." ${ }^{13}$ This is very much a departure from life cycle theory as it is conventionally articulated.

What significance do these advances have for aggregate saving in Japan? First, they call into question the usefulness of papers which presume that one behavioral paradigm is sufficient to explain aggregate saving. Second, they make extremely clear that detailed studies on the wealth and income distributions of saving in Japan are absolutely vital. And, finally, they suggest that aggregate saving in Japan may be a far more complex process than has been generally appreciated to date.

13. Carroll and Summers (1991), p. 339. 
Conclusion

Japan's saving has provided the funds for investment that have fueled the extraordinary growth of the Japanese economy over the postwar period. And in a structural sense this saving is the explanation for Japan's string of fairly large current account surpluses over the past ten years. I have also tried to argue here that Japan is a good illustration of the maxim that increased saving leads to increased investment and greater growth.

Turning to research developments since about 1984 , much of the difference in levels between US and Japanese saving rates can be attributed to differing accounting conventions. When these are standardized it becomes clear in particular that the idea that the Japanese private saving rate is high is fifteen years out of date. In a similar vein the death knell is about to sound for the hypothesis that special factors more or less idiosyncratic to Japan have contributed significantly to the aggregate saving rate. Finally in America it seems that diversity in saving behavior is important in determining aggregate saving. If for some years now American and Japanese private saving behavior have not been all that different it might be the case that diversity in saving behavior is also important in determining aggregate saving in Japan. This is certainly a line of inquiry that deserves the greatest attention. 
REFERENCES

Altonji, J. G., Hayashi, F., and L. J. Kotlikoff (1992). "Is the Extended Family Altruistically Linked? Direct Tests Using Micro Data," American Economic Review, 82:5.

Avery, R. B. and A. B. Kennickell (1991). "Household Saving in the U.S.," Review of Income and Wealth, 37:4.

Bush, G. (1990). Economic Report of the President 1990, Washington: United States Government Printing office.

Bush, G. (1993). Economic Report of the President 1993, Washington: United States Government Printing office.

Campbell, D. W. (1992). "Transfer and Life Cycle Wealth in Japan, 1974-1984," Working Paper No. 68, Jerome Levy Economics Institute of Bard College.

Carroll, C. D. and L. H. Summers (1991). "Consumption Growth Parallels Income Growth: Some New Evidence," in National Saving and Economic Performance, eds. B. D. Bernheim and J. B. Shoven, Chicago: University of Chicago Press.

Christiano, L. J. (1989). "Understanding Japan's Saving Rate: The Reconstruction Hypothesis," Federal Reserve Bank of Minneapolis Quarterly Review, 13:2.

Deaton, A. S. (1990). "Saving in Developing Countries: Theory and Review," World Bank Economic Review, Special Issue, Proceedings of the First Annual World Bank Conference on Development Economics.

Deaton, A. S. (1992). Understanding Consumption, Oxford: Clarendon Press.

Dekle, R. (1989). "The Unimportance of Intergenerational Transfers in Japan," Japan and the World Economy, 1:4.

Dekle, R. and L. Summers (1991). "Japan's High Saving Rate Reaffirmed," Bank of Japan Monetary and Economic Studies, $9: 2$.

Economic Planning Agency (1988). Report on National Accounts from 1955 to 1969, Tokyo: Ministry of Finance Printing Bureau.

Economic Planning Agency (1991). Report on Revised National Accounts on the basis of 1985, Volumes 1 and 2, Tokyo: Ministry of Finance Printing Bureau. 
Economic Planning Agency (1994). Annual Report on National Accounts 1994, Tokyo: Ministry of Finance Printing Bureau.

Feldstein, M. and P. Bacchetta (1991). "National Saving and International Investment," in National Saving and Economic Performance, eds. B. D. Bernheim and J. B. Shoven, Chicago: University of Chicago Press.

Feldstein, M. and C. Y. Horioka (1980). "Domestic Saving and International Capital Flows," Economic Journal, 90.

Hall, R. E. (1978). "Stochastic Implications of the Life CyclePermanent Income Hypothesis: Theory and Evidence," Journal of Political Economy, 96 .

Hayashi, F. (1986). "Why is Japan's Saving Rate so Apparently High?" in NBER Macroeconomics Annual 1986, Volume 1, ed. $S$. Fischer, Cambridge: MIT Press.

Hayashi, F. (1991). "Rejoinder to Dekle and Summers," Bank of Japan Monetary and Economic Studies, 9:2 .

Hayashi, F. (1994). "Japan's Saving Rate: An Update," paper presented at the Osaka-Columbia Joint Conference on Developments in the Japanese Economy and its Pacific Context (June 8-9), Osaka.

Horioka, C. Y. (1988). "Saving for Housing Purchase in Japan," Journal of the Japanese and International Economies, 2:3.

Horioka, C. Y. (1989). "Saving, IS Balances, and U.S.-Japan Trade and Investment Friction," Discussion Paper 208, Institute of Social and Economic Research, Osaka University.

Horioka, C. Y. (1990). "Why is Japan's Household Saving Rate So High? A Literature Survey," Journal of the Japanese and International Economies, $4: 1$.

Horioka, C. Y. et al. (1991). "On the Importance of Saving for Specific Motives, Part 4, Housing Purchase," Finansharu Rebyu, Institute of Fiscal and Monetary Policy, Ministry of Finance, 20 (in Japanese).

Horioka, C. Y. (1993). "Saving in Japan," in World Savings: An International Survey, ed. A. Heertje, oxford: Blackwell Publishers.

Horioka, C. Y. (May 1994). "Is Japan's Household Saving Rate Really High?" mimeo, Institute of Social and Economic Research, Osaka University. 
IMF Statistics Department (1993). International Financial Statistics Yearbook 1993, Washington: International Monetary Fund.

Ishikawa, T. and K. Ueda (1984). "The Bonus Payment system and Japanese Personal Saving," in The Economic Analysis of the Japanese Firm, ed. M. Aoki, Amsterdam: North-Holland.

Iwamoto, Y. (1994). "Japan's Saving Rate is Indeed Lower than Professor Hayashi Revealed," mimeo, Kyoto University.

Kotlikoff, L. J. and L. H. Summers (1981). "The Role of Intergenerational Transfers in Aggregate Capital Accumulation," Journal of Political Economy, 89:4.

Laitner, J. (1992). "Random Earnings Differences, Lifetime Liquidity Constraints, and Altruistic Intergenerational Transfers," Journal of Economic Theory, 58:2.

Management and Coordination Agency, Statistics Bureau (1993). Japan Statistical Yearbook 1993/94, Tokyo: Ministry of Finance Printing Bureau.

Modigliani, F. (1988). "Measuring the Contribution of Intergenerational Transfers to Total Wealth: Conceptual Issues and Empirical Findings," in Modelling the Accumulation and Distribution of Wealth, eds. D. Kessler and A. Masson, Oxford: Clarendon Press.

Takenaka, H. and K. Ogawa (1987). Taigai Fukinko no Makuro Bunseki: Chochiku/Toshi Baransu to Seisaku Kyocho (A Macroeconomic Analysis of External Disequilibria: The SavingInvestment Balance and Policy Coordination), Tokyo: Toyo Keizai Shinposha.

U.S. Department of Commerce, Bureau of Economic Analysis (1992). National Income and Product Accounts of the United states: Volume 2, 1959-88, Washington: United states Government Printing office.

U.S. Department of Commerce, Bureau of Economic Analysis (1993a). Survey of Current Business, Washington: United States Government Printing office, 73:8.

U.S. Department of Commerce, Bureau of Economic Analysis (1993b). National Income and Product Accounts of the United States: Volume 1, 1929-58, Washington: United States Government Printing office.

U.S. Department of Commerce, Bureau of Economic Analysis (1994). Survey of current Business, Washington: United states Government Printing office, 74:3. 
Table 1

Sectoral IS Balances in Japan

(\& NNP)

\begin{tabular}{|c|c|c|c|c|c|c|c|c|c|c|c|c|c|c|c|}
\hline \multirow[t]{2}{*}{ Year } & \multicolumn{2}{|c|}{ Household } & \multirow{2}{*}{$\begin{array}{l}\text { sector } \\
\text { S-I }\end{array}$} & \multicolumn{2}{|c|}{ Business } & \multirow{2}{*}{$\begin{array}{l}\text { sector } \\
\qquad S-I\end{array}$} & \multicolumn{3}{|c|}{ Private sector } & \multicolumn{3}{|c|}{$\begin{array}{c}\text { Government } \\
\text { sector }\end{array}$} & \multicolumn{3}{|c|}{ Economy-wide } \\
\hline & $s$ & $\mathbf{I}$ & & s & I & & $S$ & I & $-I$ & $\mathbf{S}$ & I & $S-I$ & $\mathbf{S}$ & I & $S-I$ \\
\hline $\begin{array}{l}1955 \\
1956 \\
1957 \\
1958 \\
1959\end{array}$ & $\begin{array}{l}10.2 \\
10.9 \\
10.2 \\
10.3 \\
11.3\end{array}$ & $\begin{array}{l}1.9 \\
1.1 \\
2.3 \\
2.3 \\
2.2\end{array}$ & 9.1 & $\begin{array}{l}1.3 \\
1.5 \\
4.1 \\
2.9 \\
3.6\end{array}$ & $\begin{array}{r}7.7 \\
12.1 \\
16.0 \\
10.9 \\
13.4\end{array}$ & $\begin{array}{r}-6.3 \\
-10.6 \\
-11.8 \\
-8.0 \\
-9.7\end{array}$ & $\begin{array}{l}11.6 \\
12.4 \\
14.4 \\
13.2 \\
14.9\end{array}$ & $\begin{array}{r}9.6 \\
13.2 \\
18.2 \\
13.2 \\
15.6\end{array}$ & $\begin{array}{r}2.0 \\
-.7 \\
-3.9 \\
0.0 \\
-.7\end{array}$ & $\begin{array}{l}3.7 \\
5.1 \\
6.0 \\
4.7 \\
5.3\end{array}$ & $\begin{array}{l}4.6 \\
4.2 \\
4.4 \\
4.6 \\
4.4\end{array}$ & $\begin{array}{r}-.9 \\
.9 \\
1.6 \\
.1 \\
.9\end{array}$ & $\begin{array}{l}15.3 \\
17.5 \\
20.4 \\
17.9 \\
20.2\end{array}$ & $\begin{array}{l}14.2 \\
17.4 \\
22.6 \\
17.8 \\
20.0\end{array}$ & $\begin{array}{r}1.1 \\
.1 \\
-2.3 \\
.1 \\
.2\end{array}$ \\
\hline $\begin{array}{l}1960 \\
1961 \\
1962 \\
1963 \\
1964\end{array}$ & $\begin{array}{l}11.3 \\
12.2 \\
12.0 \\
11.6 \\
12.0\end{array}$ & $\begin{array}{l}1.9 \\
2.3 \\
2.8 \\
3.1\end{array}$ & $\begin{array}{r}8.9 \\
10.3 \\
9.7 \\
8.9 \\
9.0\end{array}$ & $\begin{array}{l}7.0 \\
7.2 \\
5.3 \\
5.2 \\
4.9\end{array}$ & $\begin{array}{l}18.0 \\
22.4 \\
17.6 \\
16.4 \\
16.3\end{array}$ & $\begin{array}{l}-11.0 \\
-15.2 \\
-12.3 \\
-11.2 \\
-11.4\end{array}$ & $\begin{array}{l}18.3 \\
19.4 \\
17.3 \\
16.8 \\
16.9\end{array}$ & $\begin{array}{l}20.4 \\
24.3 \\
19.9 \\
19.2 \\
19.4\end{array}$ & $\begin{array}{l}-2.1 \\
-4.9 \\
-2.6 \\
-2.4 \\
-2.4\end{array}$ & $\begin{array}{l}6.4 \\
7.5 \\
7.3 \\
6.8 \\
6.6\end{array}$ & $\begin{array}{l}4.5 \\
4.7 \\
5.7 \\
5.6 \\
5.7\end{array}$ & $\begin{array}{r}2.0 \\
2.8 \\
1.6 \\
1.2 \\
.9\end{array}$ & $\begin{array}{l}24.7 \\
26.9 \\
24.6 \\
23.6 \\
23.5\end{array}$ & $\begin{array}{l}24.8 \\
29.0 \\
25.6 \\
24.8 \\
25.0\end{array}$ & $\begin{array}{l}-.1 \\
-2.1 \\
-1.0 \\
-1.2 \\
-1.5\end{array}$ \\
\hline $\begin{array}{l}1965 \\
1966 \\
1967 \\
1968 \\
1969\end{array}$ & $\begin{array}{l}12.5 \\
11.6 \\
10.6 \\
12.6 \\
12.5\end{array}$ & $\begin{array}{l}4.0 \\
4.0 \\
4.5 \\
4.5 \\
4.1\end{array}$ & $\begin{array}{l}6.0 \\
8.2 \\
8.5\end{array}$ & $\begin{array}{l}3.6 \\
5.8 \\
8.7 \\
8.6 \\
9.7\end{array}$ & $\begin{array}{l}12.4 \\
15.7 \\
17.4 \\
18.6\end{array}$ & $\begin{array}{l}-8.5 \\
-6.6 \\
-7.1 \\
-8.8 \\
-8.9\end{array}$ & $\begin{array}{l}17.4 \\
19.3 \\
21.2 \\
22.2\end{array}$ & $\begin{array}{l}16.1 \\
16.4 \\
20.3 \\
21.9 \\
22.6\end{array}$ & $\begin{array}{r}0.0 \\
1.0 \\
-1.0 \\
-.6 \\
-.4\end{array}$ & $\begin{array}{l}6.1 \\
5.6 \\
6.4 \\
6.5 \\
6.9\end{array}$ & $\begin{array}{l}6.0 \\
5.5 \\
5.6 \\
5.5\end{array}$ & $\begin{array}{r}.5 \\
-.4 \\
.9 \\
1.0 \\
1.4\end{array}$ & $\begin{array}{l}22.2 \\
23.0 \\
25.6 \\
27.8 \\
29.1\end{array}$ & $\begin{array}{l}21.6 \\
22.4 \\
25.8 \\
27.4 \\
28.2\end{array}$ & $\begin{array}{r}.6 \\
.6 \\
-.1 \\
.3 \\
.9\end{array}$ \\
\hline $\begin{array}{l}1970 \\
1971 \\
1972 \\
1973 \\
1974\end{array}$ & $\begin{array}{l}12.8 \\
13.4 \\
14.0 \\
16.0 \\
18.9\end{array}$ & $\begin{array}{l}4.5 \\
2.6 \\
2.4 \\
2.8 \\
5.7\end{array}$ & $\begin{array}{r}8.3 \\
10.9 \\
11.6 \\
13.2 \\
13.2\end{array}$ & $\begin{array}{r}10.7 \\
7.1 \\
7.3 \\
5.8 \\
.5\end{array}$ & $\begin{array}{l}19.6 \\
16.7 \\
15.8 \\
18.3 \\
15.3\end{array}$ & $\begin{array}{r}-8.9 \\
-9.6 \\
-8.4 \\
-12.5 \\
-14.8\end{array}$ & $\begin{array}{l}23.5 \\
20.5 \\
21.3 \\
21.8 \\
19.4\end{array}$ & $\begin{array}{l}24.1 \\
19.3 \\
18.1 \\
21.1 \\
21.0\end{array}$ & $\begin{array}{r}-.6 \\
1.2 \\
3.2 \\
.7 \\
-1.6\end{array}$ & $\begin{array}{l}7.6 \\
7.8 \\
7.0 \\
7.9 \\
7.3\end{array}$ & $\begin{array}{l}5.7 \\
6.5 \\
7.1 \\
7.3 \\
6.8\end{array}$ & $\begin{array}{r}1.9 \\
1.3 \\
-.1 \\
.6 \\
.4\end{array}$ & $\begin{array}{l}31.1 \\
28.3 \\
28.3 \\
29.7 \\
26.7\end{array}$ & $\begin{array}{l}29.8 \\
25.8 \\
25.2 \\
28.4 \\
27.9\end{array}$ & $\begin{array}{r}1.3 \\
2.5 \\
3.1 \\
1.3 \\
-1.2\end{array}$ \\
\hline $\begin{array}{l}1975 \\
1976 \\
1977 \\
1978 \\
1979\end{array}$ & $\begin{array}{l}19.5 \\
19.9 \\
18.3 \\
17.5 \\
15.0\end{array}$ & $\begin{array}{l}6.3 \\
7.0 \\
6.3 \\
7.0 \\
5.8\end{array}$ & $\begin{array}{r}13.2 \\
13.0 \\
12.0 \\
10.5 \\
9.2\end{array}$ & $\begin{array}{r}-.8 \\
.8 \\
1.5 \\
3.8 \\
4.0\end{array}$ & $\begin{array}{l}9.9 \\
8.8 \\
7.8 \\
6.4 \\
8.9\end{array}$ & $\begin{array}{r}-10.7 \\
-7.9 \\
-6.3 \\
-2.7 \\
-4.9\end{array}$ & $\begin{array}{l}18.7 \\
20.8 \\
19.8 \\
21.2 \\
19.0\end{array}$ & $\begin{array}{l}-6.1 \\
-5.7 \\
-4.1 \\
-3.4 \\
-4.7\end{array}$ & $\begin{array}{l}2.6 \\
5.0 \\
5.7 \\
7.8 \\
4.3\end{array}$ & $\begin{array}{l}3.6 \\
2.3 \\
2.6 \\
1.6 \\
2.7\end{array}$ & $\begin{array}{l}6.8 \\
6.5 \\
7.0 \\
7.9 \\
8.1\end{array}$ & $\begin{array}{l}-32 \\
-4.2 \\
-4 \\
-6 \\
-5\end{array}$ & $\begin{array}{l}22.3 \\
23.0 \\
22.4 \\
22.8 \\
21.8\end{array}$ & $\begin{array}{l}23.0 \\
22.2 \\
21.1 \\
21.3 \\
22.9\end{array}$ & $\begin{array}{r}-.6 \\
.8 \\
1.3 \\
1.6 \\
-1.1\end{array}$ \\
\hline
\end{tabular}




\begin{tabular}{|c|c|c|c|c|c|c|c|c|c|c|c|c|c|c|c|}
\hline $\begin{array}{l}1980 \\
1981 \\
1982 \\
1983 \\
1984\end{array}$ & $\begin{array}{l}14.8 \\
15.2 \\
13.8 \\
13.4 \\
12.9\end{array}$ & $\begin{array}{l}4.5 \\
3.6 \\
3.4 \\
2.8 \\
2.5\end{array}$ & $\begin{array}{l}10.3 \\
11.7 \\
10.5 \\
10.6 \\
10.4\end{array}$ & $\begin{array}{l}3.3 \\
2.4 \\
2.8 \\
2.7 \\
3.3\end{array}$ & $\begin{array}{l}9.8 \\
9.3 \\
8.4 \\
7.1 \\
8.2\end{array}$ & $\begin{array}{l}-6.5 \\
-6.9 \\
-5.6 \\
-4.4 \\
-4.9\end{array}$ & $\begin{array}{l}18.1 \\
17.6 \\
16.6 \\
16.1 \\
16.2\end{array}$ & $\begin{array}{r}14.3 \\
12.8 \\
11.7 \\
9.9 \\
10.6\end{array}$ & $\begin{array}{l}3.7 \\
4.8 \\
4.9 \\
6.2 \\
5.6\end{array}$ & $\begin{array}{l}3.0 \\
3.5 \\
3.2 \\
2.7 \\
3.7\end{array}$ & $\begin{array}{l}8.0 \\
7.9 \\
7.4 \\
6.9 \\
6.1\end{array}$ & $\begin{array}{l}-5.1 \\
-4.4 \\
-4.1 \\
-4.2 \\
-2.4\end{array}$ & $\begin{array}{l}21.0 \\
21.1 \\
19.8 \\
18.7 \\
19.9\end{array}$ & $\begin{array}{l}22.4 \\
20.8 \\
19.1 \\
16.7 \\
16.8\end{array}$ & $\begin{array}{r}-1.3 \\
.4 \\
.7 \\
2.0 \\
3.2\end{array}$ \\
\hline $\begin{array}{l}1985 \\
1986 \\
1987 \\
1988 \\
1989\end{array}$ & $\begin{array}{l}12.5 \\
12.9 \\
11.7 \\
11.2 \\
11.4\end{array}$ & $\begin{array}{r}7-6 \\
1.8 \\
1.8 \\
1.3 \\
.7\end{array}$ & $\begin{array}{r}10.9 \\
11.2 \\
9.8 \\
9.9 \\
10.8\end{array}$ & $\begin{array}{l}3.5 \\
3.4 \\
3.2 \\
3.8 \\
2.3\end{array}$ & $\begin{array}{r}9.3 \\
8.6 \\
9.1 \\
11.7 \\
13.1\end{array}$ & $\begin{array}{r}-5.9 \\
-5.3 \\
-5.8 \\
-7.9 \\
-10.8\end{array}$ & $\begin{array}{l}16.0 \\
16.3 \\
14.9 \\
15.0 \\
13.8\end{array}$ & $\begin{array}{l}11.0 \\
10.4 \\
10.9 \\
13.0 \\
13.8\end{array}$ & $\begin{array}{l}5.0 \\
5.9 \\
4.0 \\
2.0 \\
0.0\end{array}$ & $\begin{array}{l}4.9 \\
4.7 \\
6.6 \\
7.9 \\
9.1\end{array}$ & $\begin{array}{l}5.9 \\
5.8 \\
6.0 \\
6.2 \\
6.2\end{array}$ & $\begin{array}{r}-.9 \\
-1.1 \\
.5 \\
1.7 \\
z-9\end{array}$ & $\begin{array}{l}20.9 \\
21.0 \\
21.5 \\
22.9 \\
22.9\end{array}$ & $\begin{array}{l}16.8 \\
16.2 \\
17.0 \\
19.2 \\
20.0\end{array}$ & $\begin{array}{l}4.1 \\
4.8 \\
4.5 \\
3.7 \\
2.9\end{array}$ \\
\hline $\begin{array}{l}1990 \\
1991 \\
1992\end{array}$ & $\begin{array}{l}11.1 \\
11.8 \\
11.3\end{array}$ & $\begin{array}{l}1.1 \\
1.3 \\
2.4\end{array}$ & $\begin{array}{r}11.2 \\
10.5 \\
8.9\end{array}$ & $\begin{array}{r}2.1 \\
1.1 \\
.5\end{array}$ & $\begin{array}{r}14.7 \\
12.3 \\
8.5\end{array}$ & $\begin{array}{r}-12.6 \\
-11.3 \\
-7.9\end{array}$ & $\begin{array}{l}13.2 \\
12.9 \\
11.8\end{array}$ & $\begin{array}{l}14.6 \\
13.6 \\
10.8\end{array}$ & $\begin{array}{r}-1.4 \\
1.8 \\
1.0\end{array}$ & $\begin{array}{r}9.8 \\
10.5 \\
9.6\end{array}$ & $\begin{array}{l}6.4 \\
7.0 \\
7.4\end{array}$ & $\begin{array}{l}3.4 \\
3.5 \\
2.2\end{array}$ & $\begin{array}{l}\mathrm{ZH}, 0 \\
23.3 \\
21.4\end{array}$ & $\begin{array}{l}z 7.0 \\
20.7 \\
18.2\end{array}$ & $\begin{array}{l}2.0 \\
2.7\end{array}$ \\
\hline
\end{tabular}

Notes: S represents saving, and I represents investment.

I plus S-I do not sum to $\mathrm{S}$ in some cases due to rounding error.

All figures are in percent of net national product.

The household sector includes households, private unincorporated non-financial enterprises, and private non-profit institutions serving households. The business sector consists of financial institutions and non-financial incorporated enterprises.

Sources: Economic Planning Agency (1988), (1991), and (1994). 
Table 2

Japan's Current Account Balances, 1970-1992

(billions of dollars)

$\begin{array}{ll}\text { Year } & \text { Amount } \\ 1970 & 1.99 \\ 1971 & 5.80 \\ 1972 & 6.64 \\ 1973 & -.13 \\ 1974 & -4.72 \\ 1975 & -.68 \\ 1976 & 3.71 \\ 1977 & 10.91 \\ 1978 & 16.54 \\ 1979 & -8.74 \\ 1980 & -10.75 \\ 1981 & 4.77 \\ 1982 & 6.85 \\ 1983 & 20.80 \\ 1984 & 35.00 \\ 1985 & 49.17 \\ 1986 & 85.83 \\ 1987 & 87.02 \\ 1988 & 79.61 \\ 1989 & 56.99 \\ 1990 & 35.87 \\ 1991 & 72.91 \\ 1992 & 117.64\end{array}$

Source: IMF Statistics Department (1993) 
Table 3

Sectoral IS Balances in the United States, 1995-1992

$(\%$ NNP)

\begin{tabular}{|c|c|c|c|c|c|}
\hline Year & $\begin{array}{l}\text { Net private } \\
\text { saving }\end{array}$ & $\begin{array}{l}\text { Net private } \\
\text { domestic } \\
\text { investment }\end{array}$ & $\begin{array}{l}\text { Private } \\
\text { S-I } \\
\text { balance }\end{array}$ & $\begin{array}{l}\text { Government } \\
\text { surplus }\end{array}$ & $\begin{array}{l}\text { Economy-wide } \\
\text { S-I } \\
\text { balance }\end{array}$ \\
\hline $\begin{array}{l}1955 \\
1956 \\
1957 \\
1958 \\
1959\end{array}$ & $\begin{array}{l}8.3 \\
8.7 \\
8.6 \\
8.4 \\
8.4\end{array}$ & $\begin{array}{l}9.3 \\
8.7 \\
7.2 \\
5.3 \\
7.6\end{array}$ & $\begin{array}{r}-1.0 \\
0.0 \\
1.4 \\
3.1 \\
.8\end{array}$ & $\begin{array}{r}.8 \\
1.4 \\
.2 \\
-2.6 \\
-.7\end{array}$ & $\begin{array}{r}-.2 \\
1.4 \\
1.6 \\
.5 \\
.1\end{array}$ \\
\hline $\begin{array}{l}1960 \\
1961 \\
1962 \\
1963 \\
1964\end{array}$ & $\begin{array}{l}7.5 \\
8.1 \\
8.8 \\
8.5 \\
9.6\end{array}$ & $\begin{array}{l}6.9 \\
6.2 \\
7.3 \\
7.5 \\
8.0\end{array}$ & $\begin{array}{r}.6 \\
1.9 \\
1.5 \\
1.0 \\
1.6\end{array}$ & $\begin{array}{r}.8 \\
-.6 \\
-.6 \\
. .3 \\
-.3\end{array}$ & $\begin{array}{r}1.4 \\
1.3 \\
.9 \\
1.3 \\
1.4\end{array}$ \\
\hline $\begin{array}{l}1965 \\
1966 \\
1967 \\
1968 \\
1969\end{array}$ & $\begin{array}{r}10.2 \\
9.9 \\
10.2 \\
8.8 \\
7.7\end{array}$ & $\begin{array}{l}9.3 \\
9.6 \\
8.1 \\
8.0 \\
8.3\end{array}$ & $\begin{array}{r}.9 \\
.3 \\
2.2 \\
.8 \\
-.6\end{array}$ & $\begin{array}{r}.2 \\
-.1 \\
-1.8 \\
-.6 \\
1.1\end{array}$ & $\begin{array}{r}1.1 \\
.2 \\
.4 \\
.2 \\
.5\end{array}$ \\
\hline $\begin{array}{l}1970 \\
1971 \\
1972 \\
1973 \\
1974\end{array}$ & $\begin{array}{r}8.3 \\
9.4 \\
8.6 \\
10.1 \\
8.7\end{array}$ & $\begin{array}{l}6.6 \\
7.7 \\
8.7 \\
9.9 \\
7.9\end{array}$ & $\begin{array}{r}1.7 \\
1.6 \\
-.1 \\
.2 \\
.8\end{array}$ & $\begin{array}{r}-1.2 \\
-1.9 \\
-.4 \\
.6 \\
-.3\end{array}$ & $\begin{array}{r}.4 \\
-.3 \\
-.4 \\
.7 \\
.4\end{array}$ \\
\hline $\begin{array}{l}1975 \\
1976 \\
1977 \\
1978 \\
1979\end{array}$ & $\begin{array}{l}9.8 \\
8.8 \\
8.4 \\
8.8 \\
8.3\end{array}$ & $\begin{array}{l}4.2 \\
6.5 \\
8.6 \\
9.9 \\
9.2\end{array}$ & $\begin{array}{r}5.6 \\
2.3 \\
-.2 \\
-1.1 \\
-1.0\end{array}$ & $\begin{array}{r}-4.5 \\
-2.4 \\
-.9 \\
.1 \\
.4\end{array}$ & $\begin{array}{r}1.1 \\
-.1 \\
-1.1 \\
-.9 \\
-.6\end{array}$ \\
\hline $\begin{array}{l}1980 \\
1981 \\
1982 \\
1983 \\
1984\end{array}$ & $\begin{array}{l}7.7 \\
8.3 \\
7.8 \\
7.4 \\
9.2\end{array}$ & $\begin{array}{l}6.4 \\
7.2 \\
3.8 \\
4.3 \\
8.5\end{array}$ & $\begin{array}{r}1.3 \\
1.0 \\
4.1 \\
3.1 \\
.7\end{array}$ & $\begin{array}{l}-1.5 \\
-1.1 \\
-3.9 \\
-4.6 \\
-3.2\end{array}$ & $\begin{array}{r}-.1 \\
-.1 \\
.2 \\
-1.5 \\
-2.5\end{array}$ \\
\hline $\begin{array}{l}1985 \\
1986 \\
1987 \\
1988 \\
1989\end{array}$ & $\begin{array}{l}7.8 \\
6.4 \\
5.7 \\
6.1 \\
5.1\end{array}$ & $\begin{array}{l}7.2 \\
6.3 \\
6.1 \\
5.9 \\
5.4\end{array}$ & $\begin{array}{r}.6 \\
. .1 \\
-.5 \\
. .2 \\
-.3\end{array}$ & $\begin{array}{l}-3.5 \\
-3.9 \\
-2.8 \\
-2.2 \\
-1.7\end{array}$ & $\begin{array}{l}-2.9 \\
-3.8 \\
-3.2 \\
-2.0 \\
-1.9\end{array}$ \\
\hline $\begin{array}{l}1990 \\
1991 \\
1992\end{array}$ & $\begin{array}{l}5.2 \\
5.9 \\
6.1\end{array}$ & $\begin{array}{l}4.2 \\
2.2 \\
2.6\end{array}$ & $\begin{array}{l}1.1 \\
3.8 \\
3.5\end{array}$ & $\begin{array}{l}-2.8 \\
-3.8 \\
-5.0\end{array}$ & $\begin{array}{r}-1.7 \\
-.1 \\
-1.5\end{array}$ \\
\hline
\end{tabular}


Notes: All figures are in percent of net national product.

Any discrepancies in totals are due to rounding error.

All items in this table were computed according to the definitions of the National Income and Product Accounts.

Sources: U.S. Department of Commerce (1992), (1993a), (1993b), and (1994). 
Table 4

U.S.-Japan Comparison of Private Saving Rates, 1955-1992

Japan U.S.

Time period

$\begin{array}{lcc}1955-59 & 13.3 & 8.5 \\ 1960-64 & 17.7 & 8.5 \\ 1965-69 & 19.2 & 9.4 \\ 1970-74 & 21.3 & 9.0 \\ 1975-79 & 19.9 & 8.8 \\ 1980-84 & 16.9 & 8.1 \\ 1985-89 & 15.2 & 6.2 \\ 1990-92 & 12.6 & 5.7 \\ 1955-92 & & 8.1\end{array}$

Notes: All figures are the arithmetic average of the annual saving rates and are in percent of net national product.

Sources: Tables 1 and 3 
Table 5

U.S.-Japan Comparison of GDP Growth Rates, 1955-1992

\begin{tabular}{|c|c|c|c|c|c|c|}
\hline \multirow[t]{2}{*}{ Time period } & \multicolumn{2}{|c|}{$\begin{aligned} \text { Av } € \\
\text { Real GDI }\end{aligned}$} & \multicolumn{2}{|c|}{$\begin{array}{l}\text { Annual Growth } \\
\text { Population }\end{array}$} & \multicolumn{2}{|c|}{$\begin{array}{l}\text { Rates (percent) } \\
\text { Real Per Capita }\end{array}$} \\
\hline & Japan & U.S. & Japan & U.S. & Japan & U.S. \\
\hline $1955-59^{1}$ & 8.0 & 2.9 & .93 & 1.8 & 7.07 & 1.1 \\
\hline $1960-64$ & 10.9 & 4.0 & .96 & 1.5 & 9.94 & 2.5 \\
\hline $1965-69$ & 10.6 & 4.2 & 1.08 & 1.1 & 9.52 & 3.1 \\
\hline $1970-74$ & 6.0 & 2.5 & 1.34 & 1.1 & 4.66 & 1.4 \\
\hline $1975-79$ & 4.4 & 3.2 & .99 & 1.0 & 3.41 & 2.2 \\
\hline $1980-84$ & 3.5 & 1.8 & .70 & 1.0 & 2.80 & .8 \\
\hline $1985-89$ & 4.5 & 3.1 & .48 & .9 & 4.02 & 2.2 \\
\hline $1990-92$ & 3.4 & 1.0 & .34 & 1.1 & 3.06 & -.1 \\
\hline $1955-92^{2}$ & 6.5 & 2.9 & .88 & 1.2 & 5.62 & 1.7 \\
\hline
\end{tabular}

${ }^{1}$ For Japan, $1956-59$.

${ }^{2}$ For Japan, 1956-92.

${ }^{3}$ The real per capita GDP growth rate was computed as the difference between the real GDP growth rate and the population growth rate.

Sources: Bush (1993); Economic Planning Agency (1988), (1994); Management and Coordination Agency (1993); and U.S. Department of Commerce (1994). 
Table 6

Estimates of the Share of Transfer Wealth in Japan

\begin{tabular}{|c|c|c|c|}
\hline study & Time Period & Definition ${ }^{1}$ & $\begin{array}{l}\text { Share of transfer } \\
\text { wealth (percent) }\end{array}$ \\
\hline Hayashi (1986) & $1969-74$ & & 2.3 trillion yen ${ }^{2}$ \\
\hline Dekle (1989) & $1968-83$ & $\mathrm{KS}$ & 3 to 27 \\
\hline Campbell (1992) & $1974-84$ & $\begin{array}{l}\mathrm{M} \\
\mathrm{KS}\end{array}$ & $\begin{array}{l}0 \text { to } 23.9 \\
0 \text { to } 28.6\end{array}$ \\
\hline
\end{tabular}

${ }^{1} \mathrm{KS}$ represents the Kotlikoff-Summers definition of transfer, and $\mathrm{M}$ represents the Modigliani definition.

${ }^{2}$ This figure is Hayashi's estimate of the annual flow of transfers. 
Table 7

Share of 1983-86 US Real Saving by 1986 Wealth Classes Percent Distribution

\begin{tabular}{lcc}
\hline $\begin{array}{l}\text { Percentile of } \\
1986 \text { Wealth }\end{array}$ & Real Saving & $\begin{array}{l}\text { Memo: Share of } \\
\text { Wealth }\end{array}$ \\
\hline 0 to 10 & -3.3 & 0.3 \\
10 to 20 & -6.0 & 0.9 \\
20 to 30 & -3.7 & 1.1 \\
30 to 40 & -3.5 & 1.9 \\
40 to 50 & -0.4 & 2.6 \\
50 to 60 & -2.8 & 4.2 \\
60 to 70 & -0.7 & 5.8 \\
70 to 80 & 8.8 & 7.8 \\
80 to 90 & 13.2 & 13.3 \\
90 to 100 & 98.4 & 62.0 \\
90 to 95 & 14.5 & 11.0 \\
95 to 99 & 30.2 & 20.6 \\
99 to 99.5 & 12.1 & 6.0 \\
99.5 to 100 & 41.6 & 24.4 \\
\hline
\end{tabular}

Source: Avery and Kennickell (1991) 


\section{Figure 1}

Japanese and US National Saving Rates, 1955-1990

(\% of NNP)

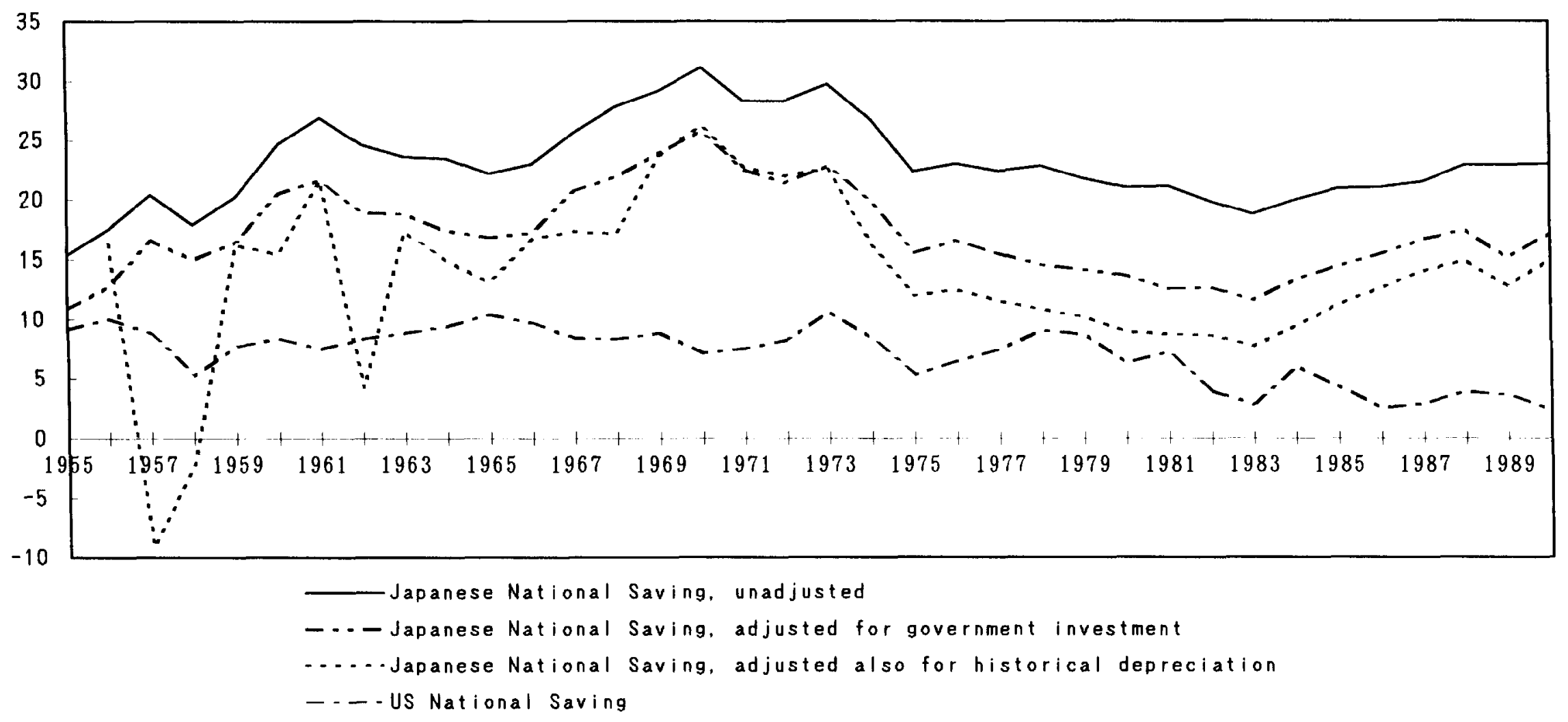

Sources: Personal communication from Hayashi (April 1994), Economic Planning Agency (1988), (1991), and (1994). 
Figure 2

Japanese and US Private Saving Rates, 1955-1990

(\% of NNP)

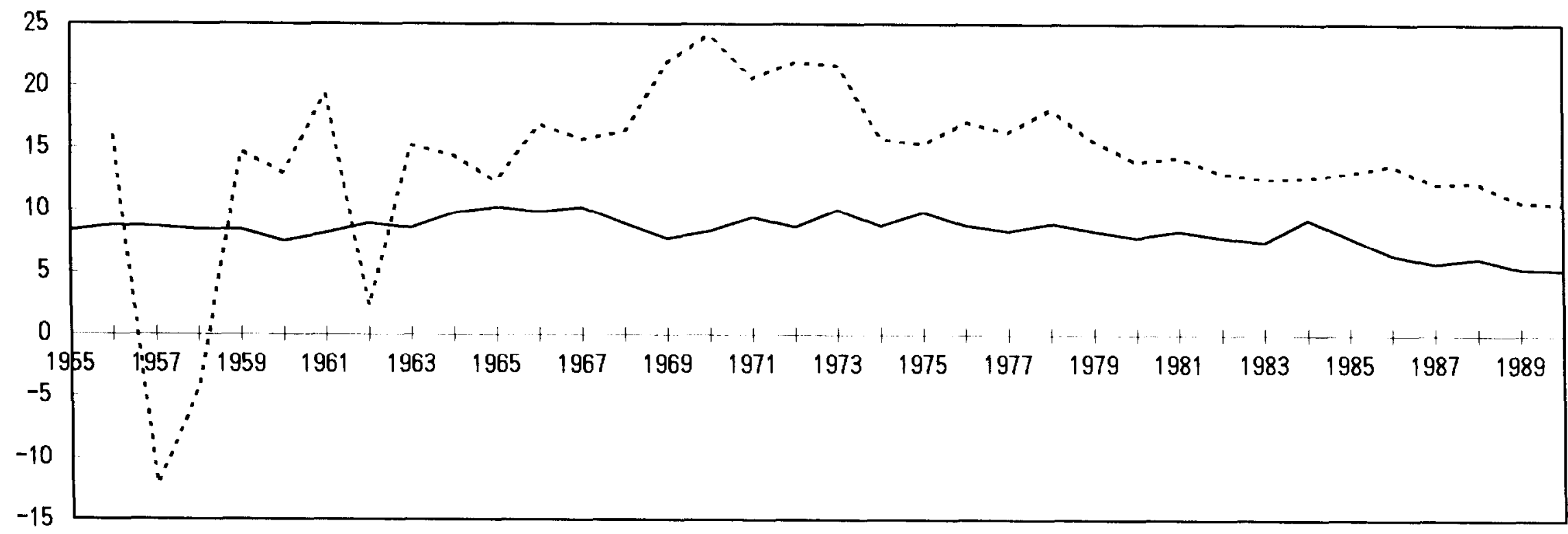

-... Japanese Private Saving Rate, adjusted

-US Private Saving Rate

Sources: Personal communication from Hayashi (April 1994), Bush (1990), (1993). 
Figure 3: Aggregate Housing-Related Saving, 1963-1989 (percent of household saving)

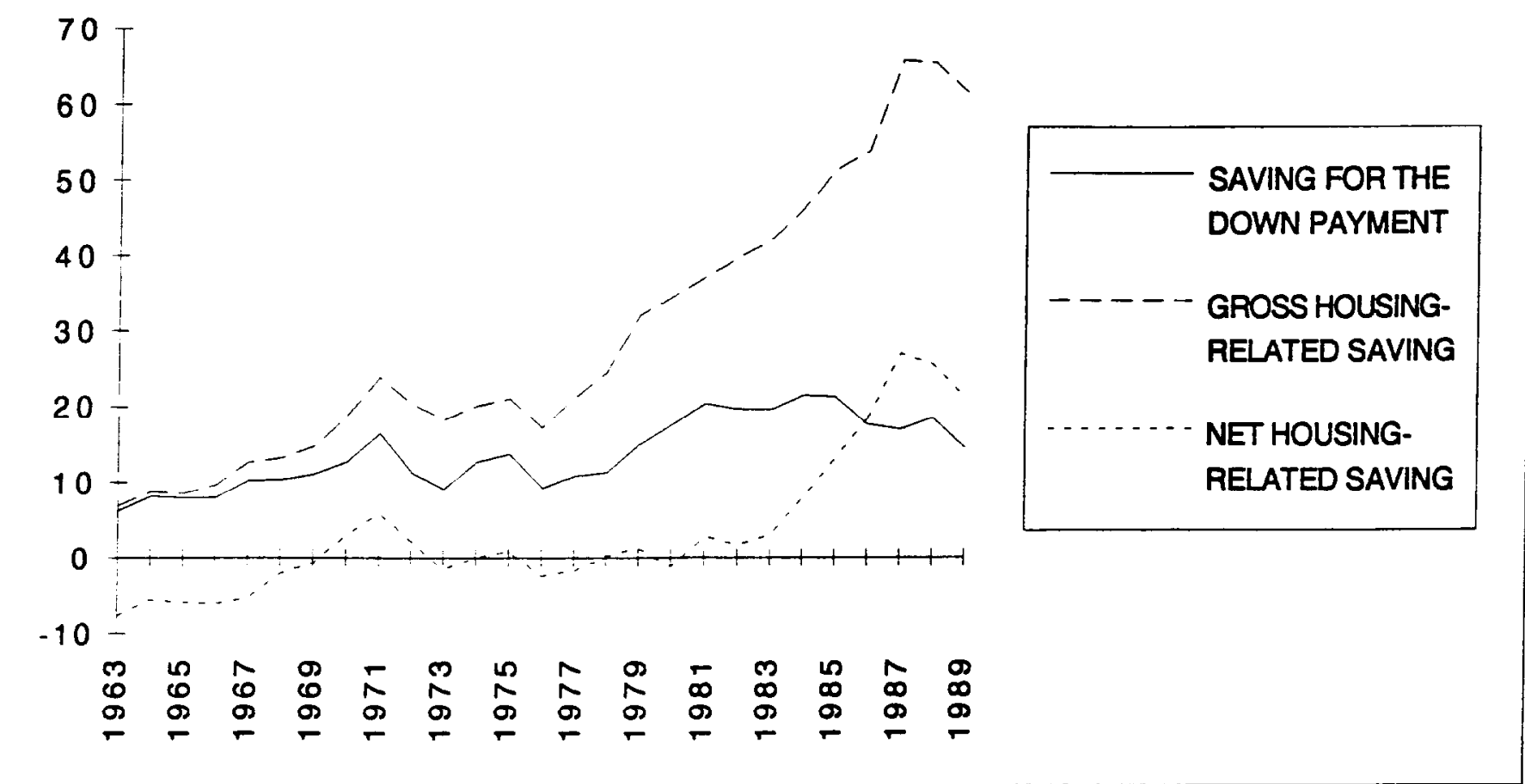

Notes: Household saving is in net terms. Depreciation in all cases is replacement cost depreciation. Source: Horioka (1991) 